\title{
Las recreaciones teatrales de Don Quijote de la Mancha de Miguel de Cervantes Saavedra en Francia (siglos XVII-XXI): estado de la cuestión y nuevos datos
}

\author{
EMMANUEL MARIGNO*
}

\section{INTRODUCCIÓN}

La recepción ultramontana del Don Quijote de Cervantes arranca poco después de la edición española de $1605^{1}$, y alcanza las recientes recreaciones de 2011. La noción de «recreación» linda con las de «imitación», «adaptación» o «collage», con las que poco comparte. «La imitación es lo contrario de la creación» según Marthe Robert, quien ha demostrado el potencial dramatúrgico de la novela cervantina y apreciado las recreaciones dramatúrgicas, siempre que éstas no sean meros cortar/pegar del diálogo novelesco; los personages, tiempo, espacio y contexto recreados se ubican en un ámbito autónomo, con códigos propios. La noción de «fidelidad» para con la novela no es aquí criterio pertinente, no obstante, lo es el de «desviación».

Recrear en lengua ajena implica traducción, selección de capítulos, nuevos decorados, diálogos, espacio-tiempo, estructuras y personajes. En la puesta en escena radica gran parte de la modernización de la novela y la proyección de ideologías contemporáneas ${ }^{3}$. Podemos clasificar los recursos de la recreación teatral en tres categorías: «elipsis», «condensación»e «inventio» ${ }^{4}$.

* Universidad Jean Monnet de Saint-Étienne, Francia.

1. Cervantes Saavedra, Miguel, El ingenioso hidalgo don Quijote de la Mancha, Compuesto por Miguel de Cervantes Saavedra, Dirigido al Duque de Bejar, Marqués de Bibraleon, Conde de Benalçar y Beñares, Vizconde de la Puebla de Alcozer, Señor de las villas de Capilla, Curiel y Burguillos, Con Privilegio en Madrid, Por Iuan de la Cuesta, Véndese en casa de Francisco Robles, Librero del Rey Nro Señor, 1605.

2. «L'imitation est le contraire de la création», Robert (1963: 35).

3. Ver Plana (2004: 255).

4. Ver Labère (1998). 
Valiosísimos estudios se publicaron al propósito entre los años 1930 y 1983: en 1930 Max-Hellmut Neumann publica «Cervantes werke in Frankreich» ${ }^{5}$, en 1931 Maurice Bardon escribe "Don Quichotte» en France au XVII et au XVIII siècles (1605-1815) ${ }^{6}$, Paul Hazard edita «Don Quichotte» de Cervantès. Etude et analyse ${ }^{7}$, Esther J. Crooks publica The Influence of Cervantes in France in the Seventeeth Century ${ }^{8}$, y, en 1983, Alexandre Cioranescu escribe Le masque et le visage. Du baroque espagnol au classicisme français ${ }^{9}$; en 1998, Claude Labère defendió su tésis Don Quichotte théâtralisé au XX siècle ${ }^{10}$ con método estético; en 1999, Muriel Plana presentó una tésis con un método histórico sobre recreaciones en literatura comparada ${ }^{11}$, que involucra el Quijote; Michel Moner, en su artículo de $2004^{12}$, sintetizó parte de estos datos con rápidas precisiones acerca del siglo XVIII, completadas por Christophe Courderc en su artículo de $2007^{13}$.

Articulo aquí lo principal de las señaladas investigaciones y, sobre todo, propongo un nuevo estado de la cuestión, basado en un corpus de cincuenta y nueve recreaciones teatrales galas de 2000 a 2011, centrándome en una aproximación a la vez estética y ética. Mi meta consiste en destacar distintos fenómenos de la transculturalidad, transescritura e intergenericidad en las recreaciones quijotescas contemporáneas.

\section{EL SIGLO XVII}

Estas recreaciones son en gran parte indisociables de la traducción que ha difundido por Francia las primeras representaciones mentales de la novela cervantina. Hasta 1614, se tradujeron primero los relatos intercalados, y no capítulos del relato principal $^{14}$; los primeros contactos con el Quijote fueron fragmentarios y desvinculados del relato central.

A la traducción de César Oudin (1614) ${ }^{15}$ sucede la de François de Rosset $(1618)^{16}$; Louis Viardot consigue la tercera traducción francesa eficiente del

5. Neumann (1930).

6. Bardon (1931).

7. Hazard (1931).

8. Crooks (1932).

9. Cioranescu (1983).

10. Ver Labère (1998).

11. Tesis dirigida por Jean-Pierre Sarrazac, y publicada en 2004 (ver nota 3).

12. Moner (2004).

13. Couderc (2007).

14. La historia de Marcela y Grisóstomo, el cuento del capitán cautivo o la novela del curioso impertinente.

15. Oudin (1614); se trata de la segunda traducción europea del Quijote, dos años después de la versión inglesa: Shelton (1612).

16. Rosset (1618). 
Quijote (1836) ${ }^{17}$; la traducción de Jean Cassou en La Pléiade (1948) ${ }^{18}$, aunque valiosa, es síntesis de las de Oudin y Rousset. Aline Schulman propone una traducción interesante (1997) ${ }^{19}$, a pesar de dirigirse a un público amplio; sin embargo, Claude Allaigre, Jean Canavaggio y Michel Moner (2001) ${ }^{20}$ traducen con rigurosos criterios científicos, a la vez que al alcance del público.

Hasta el siglo XVIII, traducir es recrear, adaptar la obra original a la lengua y horizonte cultural del público francés; sin embargo, adaptar teatralmente en lengua extranjera implica fenómenos lingüísticos, éstéticos y éticos más específicos.

Entre 1605 y 1614 brotan las primeras recreaciones francesas de la novela cervantina, que coinciden prácticamente con las traducciones de Oudin y Rousset. Estas recreaciones carnavalescas, caricaturaban el mito quijotesco estética y éticamente ${ }^{21}$. Cioranescu considera Le Ballet de don Quichot dansé par Mme. Santenir, representado en el Louvre el 3 de febrero de 1614, como la primera recreación francesa ${ }^{22}$. El tono cómico de esta primera obra dará la pauta a los epígonos ultramontanos.

En 1628, la tragicomedia de Pichou, añade rumbo ideológico con las Folies de Cardenio $^{23}$; Don Quijote aparece a partir de la quinta escena del tercer acto, sin implicación en la trama central ${ }^{24}$, y su presencia únicamente apunta a satirizar al enemigo español: estamos ante un tipo de reescritura poética con manipulación política. Estéticamente, la española pareja hidalgo-escudero se vuelve una degradada pareja bravucón-aldeano, en que se confunden la figura del escudero con la del gracioso, lo cual se explica también por el fenómeno de asimilación cultural, según el que se enfrasca lo desconocido en formas $\operatorname{conocidas}^{25}$

17. Viardot (1836-1837). Las anteriores traducciones de Filleau de Saint Martin (1677-1678) y de Florian (1799) son apreciables, pero, éstas se alejan repetidas veces del texto cervantino cultural y lingüísticamente: Filleau de Saint-Martin (1678). Tiene continuación: t. V (1695) y t. VI (1713); Florian (1792: Livre IV, $\mathrm{n}^{\circ}$ 20).

18. Cassou (1949). Aunque sea síntesis de anteriores traducciones, la de J. Cassou supera las traducciones de Jean Labarthe y Xavier Cardaillac (1923-1927), de Jean Babelon (1929) y de Francis de Miomandre (1935).

19. Schulman (1997).

20. Canavaggio (2001).

21. Ver Bardon (1931: 932); Cioranescu (1983); Pompejano Natoli (1994).

22. Obra de unos meses anterior a la traducción de Oudin: Henri, Michel, Le Ballet de don Quichot dansé par Mme. Santenir le 3 février, Table des ballets à 3, 4 et 5 parties qui se trouvent dans un recueil fait en 1600 [sic] par Michel Henry, BNF., ms. f. fr. 24357.

23. Pichou, Les folies / de Cardenio / Tragi-comédie / Dédiée à Monsievr / de Saint Simon / Par le Sieur Pichov / A Paris / Chez François Targa, au premier / Pillier de la grand'Salle du Palais / Deuant les Consultations / M DXXXX / Auec privilège du Roy; Les folies de Cardenio: tragi-comédie; (suivie des) Autres oeuvres poétiques: 1630-1629, Texte établi et présenté par Jean-Pierre Leroy (1989). Esta obra será reescrita en 1720 por Charles-Antoine Coypel en Les Folies de Cardenio, un ballet en tres actos; lo mismo hará Fuzelier en 1722 con Les noces de Gamaches; parecida reescritura encontraremos por fin en Le Prince travesti ou l'Illustre aventurier (1724), de Marivaux.

24. La tragicomedia en cinco actos de Pichou, está basada en los capítulos XXIII-XXV, XXVIIXXX, XXXIII y XXXV-XXXVII del primer Quijote.

25. Ver Couderc (2007: 39 y siguientes) 
En 1639, 1640 y 1642, la trilogía de Guyon Guérin de Bouscal -en versoconstituye las primeras comedias ${ }^{26}$ de contenido filosófico, que conllevan la dicotomía entre realidad e ilusión: Dom Quixote de la Manche ${ }^{27}$, Dom Quichot de la Manche. Seconde partie ${ }^{28}$ y Gouvernement de Sanche Pansa ${ }^{29}$.

Esta segunda parte de 1640 se centra en el Quijote de 1615, más precisamente, en los capítulos I-II, V-VII, XII-XIV y XXXI-XXXV; a diferencia de la primera obra, ésta plasma de inmediato a Don Quijote como personaje central, con un tono burlesco que no llega a la sátira, a diferencia de la obra de Pichou. Notamos menos rigidez textual, más libertad en el contenido y mayor singularidad dramatúrgica: el criterio selectivo se centra en la escenificación de la locura del protagonista; Guérin de Bouscal expone una lectura más entrañable y original de la novela, con respecto a la primera adaptación de 1639.

La obra de 1642 se inspira en los capítulos LXII-LXV, LXVII, XLIX, LI y LIII de la segunda parte, recurriendo abundantemente a la «mise en abîme», quizá, bajo influencia de L'Illusion comique de Corneille. Sancho, como personaje central, proporciona mayor grado de comicidad, pero con alguna exageración, pues la locura de Don Quijote permanece en un plano similar, menguando así la dialéctica novelesca razón/imaginación. Una locura muy similar confunde hidalgo y escudero, fenómeno compartido con las demás adaptaciones ultramontanas de comedias españolas. Esta última obra de la trilogía influyó en el teatro de Molière, quien sintetizó las dos primeras obras de G. de Bouscal, en una recreación titulada Dom Quichot ou Les enchantements de Merlin (enero/febrero de 1660): en mi opinión, es difícil saber en qué medida se conforma Molière con sintetizar las dos obras de G. de Bouscal sin que le haya influido directamente la novela cervantina, pues Molière sabía español (ver Caldicott, 1979). También se interesó Molière por la última obra de la trilogía, y la interpretó en 1665 y 1678. Esta última recreación de G. de Bouscal ha de influir en dramaturgos menos encumbrados, que proporcionan obras banales basadas en lo cómico de un Sancho enloquecido, sin trascendencia estética ni ética (Christophe Couderc da la lista exhaustiva de estas obras menores del siglo XVII francés, pp. 44-45 de la señalada investigación).

Estas recreaciones vuelven a sintonizar las literaturas española y francesa -tras el corte infligido por Pichou- en una problemática poetico-filosófica común.

26. En el sentido de francés de «comédies».

27. Guérin de Bouscal (1979). La obra retoma fielmente, en los cuatro primeros actos, los capítulos XXIII-XXX, XXXVI-XXXVII y LXIV-LXVI del primer Quijote, y se inspira en los capítulos XVI-LXI del Quijote de 1615.

28. Guérin de Bouscal (1986).

29. Guérin de Bouscal (1642); también existe la edición crítica de Caldicott (1981), « T. L. F. » $\mathrm{n}^{\circ} 286$. 


\section{LOS SIGLOS XVIII-XIX}

Las primereas recreaciones dieciochescas, de corte escuetamente cómico, carecen del matiz filosófico, literario, y sociocultural que engalanan la novela cervantina. En 1705, Bellavoine representa su Sancho Pança, seguido en 1709 por Le Jaloux désabusé de Campistron ${ }^{30}$, a continuación del cual vendrá Le Curieux impertinent de Destouches ${ }^{31}$ en 1711; serán representadas en 1710 y editadas en 1711 Arlequin et Scaramouche vendangeurs y Sancho Gouverneur de l'île Barataria, de Fuzelier ${ }^{32}$; en 1726 se representa Arlequin toujours Arlequin, de Biancolelli ${ }^{33}$, y, en 1762, se da Sancho Pança dans son île de Poinsinet $^{34}$; en 1727, se interpreta Sancho Gouverneur de Thierry ${ }^{35}$. Se cierra este ciclo en 1763 con el Sancho gouverneur de Nougaret ${ }^{36}$.

Los episodios quijotescos retomados en estas obras teatrales, lo son de manera anecdótica y sin verdadera recreación, como en Le jaloux désabusé de Campistron, Le Curieux impertinent de Destouches, o en obras de Fuzelier como Arlequin et Scaramouche vendangeurs, Le Jupiter curieux impertinent (1711) y Arlequin défenseur d'Homère $(1715)^{37}$.

Estas reescrituras de reescrituras van agotando efecto en el público, y la recreación se traslada al ballet, con tono cómico primero, siendo el más famoso el Don Quichotte chez la duchesse ${ }^{38}$ de $1743^{39}$.

La revolución francesa impulsa un giro radical, pues los autores revolucionarios adaptan Don Quijote al ideal republicano: Laya estrena L'Ami des Lois $(1793)^{40}$, mientras Fabre d'Églantine representa Le Philinte de Molière $(1790)^{41}$. Por primera vez, en Francia, las representaciones de Don Quijote dejan el modo puramente burlesco o satírico, para hacerse portavoz de ideales humanos.

Un Quijote galo posrevolucionario pervive en el siglo XIX. Don Quichotte de Victorien Sardou ${ }^{42}$ plasma la recreación en el teatro-ballet heróico-cómico; se trata de una obra en tres actos y ocho "cuadros", en prosa, con canciones, música intercalada y romances.

30. Campistron (1710).

31. Destouches (1718).

32. Fuzelier (1711).

33. Biancolelli (1726).

34. Poinsinet (1762).

35. Thierry (1727).

36. Nougaret (1763).

37. Christophe Couderc proporciona una lista de obras menores perdidas o aun sin imprimir, p. 46 de la señalada invetigación.

38. Boismortier (1743).

39. Ver la presentación que hace Christophe Couderc, p. 46 del señalado estudio, de los demás ballets, óperas bufas o pantomimas, como son los de Pannard (1734 y 1740), Poinsinet y Philidor (1762), Labussière (1773) o Pleinchesnne (1778).

40. Laya (1824).

41. Fabre d'Églantine (1791).

42. Sardou (1864). 
Don Quijote es encarnado por el señor Lesueur y Sancho Panza por el señor Pradeau, actores destacados de la época. Don Quijote presencia la obra a partir de la sexta escena del primer acto; previamente, tras la apertura del telón que nos adentra en el salón de Don Quijote, Basile y Carrasco analizan la locura de Don Quijote vinculándola con los libros de caballerías, y deciden cerrarle el acceso a la bibloteca, amurallando la entrada y disimulándola detrás de un telón; Don Quijote, enfrascado en la lectura de un libro, entra en el salón y se sorprende de no hallar la entrada a la biblioteca: «Par la barbe du Cid! ... où est la porte?», exclama el personaje irrumpiendo en la obra. Don Quijote deduce que sufre un embeleco del encantador Pantafilando.

El cuarto "cuadro" del segundo acto arranca con el viaje hacia la isla de Barataria y la reyerta entre Don Quichotte y Don Fernand por la defensa de la belleza de Dulcinea; las escenas VII y VIII del segundo acto se nutren del episodio de los galeotes; el resto del acto está dedicado a la continuación de las intrigas amorosas en torno a Luscinde, lo cual conduce los personages hacia Toledo, momento en que acontece el episodio del los molinos de viento. En la quinta escena del segundo acto, es donde Don Quijote es nombrado «Chevalier de la Triste-figure»; la sexta escena del segundo acto trata del gigante Pantafilando y de la princesa Micomicona; la novena escena del segundo acto, con Basile y Carrasco, anuncia el regreso de Don Quijote a casa, mientras va acercándose el tercer acto eslabonado con el episodio de la velada de armas.

El tercer acto arranca con un decorado de cueva en Sierra Morena; los actores de la compañía de «Angula le Mauvais» encarnan el Amor, el Demonio y los reyes; el octavo y último cuadro, que cierra a la vez el tercer acto y la obra, nos ubica en un decorado destinado a la celebración de las tres bodas. Aquí, Don Quijote no muere, incluso recobra la cordura.

Esta obra romanticista sigue pues el impulso de las recreaciones revolucionarias, rehusando un Don Quijote básicamente burlesco, y, sin contenido filosófico; el romanticismo ofrece un espectáculo total (baile, canto, declamación de textos, juesgo dramatúrgico, música, poesía y prosa), con esmerado decorado; también vuelve a la novela cervantina retomando el nombre de los personajes y con la presencia de elementos de índole española, como son toreros o romances; se plantea la locura de Don Quijote en términos literarios y no patológicos, lejos ya de las adaptaciones barrocas. Esta recreación romanticista va trasladando las escenificaciones galas hacia la intergenericidad, el pathos y la reflexión sobre la dimensión literaria y ontológica de la novela. En cierta medida, V. Sardou anuncia lo que serán las adaptaciones ultramontanas de los siglos XX y XXI. 


\section{LOS SIGLOS XX Y XXI}

A partir del siglo XX, aumenta el número de recreaciones. A Don Quichotte (1905), drama heróico-cómico de Jean Richepin ${ }^{43}$, sucede Bip interprète Don Quichotte, del mismo Marcel Marceau. En 1965, Yves Jamiaque propone su Don Quichotte (1965) ${ }^{44}$, y Serge Ganzl Le Quichotte. Chevalier d'Errance $(1973)^{45}$; lo mismo harán Georges Berdot con L’ingénieux hidalgo Don Quichotte (1989) ${ }^{46}$, Maryse Lefebvre con Quichotte (1993) ${ }^{47}$ y Vincent Bady con Quijotypanza $(1992)^{48}$. Dau y Catella cierran estas serie de fructíferas recreaciones en $2000^{49}$.

Estas recreaciones se basan en lo cómico y en los recursos del diálogo dramatúrgico. El tema de la justicia abunda en estas obras, mediante episodos como los azotes de Andrés (I, 4) o la liberación de los galeotes (I, 22); también la locura del protagonista es fuente de inspiración, sea a costa de Don Quijote y Sancho, sea contra quienes intentan mofarse de su locura, como en el Quichotte de Nele Paxinou (1992) (50; $^{5}$ vuelven a ser los mismos capítulos los que asoman al escenario como son los molinos (I, 8), el rebaño de carneros (I, 18), el encuentro con los comediantes de «Las Cortes de la Muerte» (II, 11) o la estancia en el palacio de los Duques (II, 30-57). Estas recreaciones tratan de modo desigual la muerte de Don Quijote: sea aparece como simple punto final como en Quijotypanza de Vincent Bady o Quichotte de Maryse Lefebvre, sea tratando la muerte como calderón de la obra, lo que hace Jean-Luc Bosc en Don Quichotte $(1993)^{51}$. Dos obras tratan de modo singular la muerte del protagonista: Georges Berdot, en L'ingénieux hidalgo Don Quichotte de la Manche (1989) $)^{52}$, escenifica a un chico presenciando con serenidad y sonrisa la muerte de su tío, mientras François Joxe, en Don Quichotte $(1990)^{53}$, deja morir al protagonista sin que renuncie a sus sueños y valores.

Entre las adaptaciones sinfónicas, destacan la comedia heroica Don Quichotte $(1910)^{54}$ de Massenet y la comedia musical de Jacques Brel, L'homme de La Mancha (1968) $)^{55}$; en ambas obras dialogan lo cómico y lo patético.

43. Richepin (1905).

44. Jamiaque, Yves, Don Quichotte, 12 de febrero de 1965, Teatro « Les Célestins », Lyon, escenificación de Jean-Paul le Chanois, con Philippe Clay en Don Quijote y Robert Darmel de Sancho Panza.

45. Ganzl, Serge, Le Quichotte. Chevalier d'Errance, puesta en escena de Gabriel Garran, 27 Festival de Avignon, 11 de julio a 12 de agosto de 1973; con Rufus de Don Quijote, Pierre Santini de Sancho Panza y Vanina Michel de Dulcinea.

46. Berdot (1989) en Labère (1998: III, 652-725).

47. Lefebvre (1993); Labère (1998: III, 810-843).

48. Bady (1992) en Labère (1998: III, 604-651).

49. Catella, Jean-Marc, Dau, Jacques, Mais qui est don(c) Quichotte?, Festival de Avignon, julio de 2000 .

50. Paxinou (1992) en Labère (1998: III, 844-912).

51. Bosc (1993) en Labère (1998: III, 726-760).

52. Berdot (1989) en Labère (1998: III, 652-725).

53. Joxe (1990) en Labère (1998: III, 761-809).

54. Massenet (1910).

55. Brel (1968). 


\section{EL PERIODO 2000-2011}

He destacado un corpus de 59 recreaciones teatrales en lengua francesa ${ }^{56}$, de las cuales 3 creadas en Bélgica, 1 en Montreal, 1 en Quebec, 1 en Nigeria y otra que incluye pasajes en lengua española ${ }^{57}$. El corpus presenta una coherencia de forma y contenido, como si la lengua mantuviese cierta unidad, por encima de los matices culturales de la fracofonía. Prestaré particular atención a las 53 obras creadas en el terriorio francés, incluyendo en algunos comentarios las demás.

He notado tres categorías de recreaciones teatrales: teatro convencional, teatro intergenérico -con arte circense, baile, canto, marionetas y músicay teatro multimedia -con proyección de imágenes, recursos informáticos, sonido-. Resalta una progresión diacrónica en estas recreaciones, con el uso creciente de componentes intergenéricos y multimedia, lo cual conlleva cuatro constataciones: la gran plasticidad de la materia novelesca inicial, la gran potencialidad teatral de la obra original, el aumento cuantitativo de las recreaciones los once últimos $\operatorname{años}^{58}$ y la complejificación plástica de la puesta en escena. A modo de comparación, el número de obras declaradas en la S.A.C.D. ${ }^{59}$ entre 1864 y 1996 era de 84; pasamos de una media de 0,62 obras por año en 1864-1996 a 4,6 entre 2000-2011. Por cierto, las bases son distintas $^{60}$, a pesar de todo, la comparación indica un disparo de las creaciones teatrales quijotescas en este inicio de siglo XXI.

Existen dos tipos de recreaciones: las que arrancan de la novela cervantina -sea en versión española, sea en versión francesa- y las que resultan de una «mise en abîme» de anteriores recreaciones teatrales -sean de autores ajenos, sean propias-. Didier Galas produjo su Don Quichotte (2005) a partir de anteriores recreaciones suyas, como Ficción/Quijote ${ }^{61}$ creada para Caracas; Sous le ciel de Quichotte $(2005)^{62}$ es una creación teatral y musical realizada a partir de imágenes de la inacabada película de Orson Welles; Les Musiques de Don Quichotte (2005) de José Maria Flotats, arranca de romances de Antonio de Cabezón, Luys Milán y Cristóbal de Morales ${ }^{63}$; «Don Quichotte»

56. Las creaciones de tipo escolar o pedagógico, aunque de interés, no entran en el actual enfoque.

57. Proporciono en última página una lista con las 59 obras catalogadas.

58. Con excepción del periodo 2006-2007, en que se nota un estancamiento momentáneo.

59. «Société des Auteurs et Compositeurs Dramatiques» (Sociedad de Autores y Compositores Dramatúrgicos): http://www.sacd.fr/

60. Mi corpus procede de un rastreo sistemático en la web en 2000-2011; para el mismo periodo, la S.A.C.D. sólo registro 8 recreaciones quijotescas. Obviamente, la mayoría de estas obras no han sido declaradas como propiedad intelectual en la S.A.C.D., no obstante, han sido representadas y han participado con las demás del dinamismo de las recreaciones, incluso repetidas veces, pues la mayoría han sido objeto de múltiples representaciones.

61. Galas (2005); utiliza la traducción de Aline Schulman en cuanto a base textual, y máscaras y demás recursos de la commedia dell'arte.

62. Bonnin, Romin, Sous le ciel de Quichotte, Nîmes, noviembre de 2005. Los textos son de Jean-Claude Carrière y Dorohtée Zumstein, con proyección de imágenes de Orson Welles.

63. Flotats, José Maria, Les Musiques de Don Quichotte, Ambronay, septiembre de 2005. Con acompañamento musical del grupo «Hesperion XXI», dirigido por Jordi Savall. 
ou la folie d'aimer (2010) ${ }^{64}$ se inspira en la ópera de Massenet a la vez que de la comedia musical de Mitch Leigh y Joe Darion, traducida al francés por Jacques Brel; Don Quichotte à la plancha (2010) de Michel Crance ${ }^{65}$ ensarta la recreación de Antonio Jose da Silva del siglo XVIII y la de Jacques Brel del siglo XX.

Cuando el hypotexto es la novela cervantina, existen dos tipos de fuentes: sea el autor arranca de un texto español, sea parte de una traducción francesa. Don Quijote de la Mancha (2005) de Almudena Ruiz, procede de un texto español ${ }^{66}$; la mayoría de las demás recreaciones se basa en traducciones francesas, como la de Didier Galas inspirada en el texto de Aline Schulman.

26 de las 59 recreaciones llevan un título que dista del hipotexto cervantino. 5 títulos son juegos morfosemánticos que indican una recreación centrada en el texto, como son Mais qui est don(c) Quichotte? ${ }^{67}$, Don Quichotte à la plancha, Le songe de Don Quichotte ${ }^{68}$, Don Quichotte malgré lui ${ }^{69} \mathrm{o}$ Comment je suis devenue Don Quichotte ${ }^{70} .3$ evocan el tema específico de la búsqueda de identidad como Don Qui? ${ }^{71}$, Don Quichotte $(e)^{72}$, Don Quichotte. La véritable histoire ${ }^{73}$; de orientación amorosa son las 2 tituladas «Don

64. «Compagnie de l'Arène», «Don Quichotte» ou la folie d'aimer, Royan, noviembre de 2010.

65. Crance, Michel, Don Quichotte à la plancha, Chartres, junio de 2010.

66. Ruiz, Almudena, Don Quijote de la Mancha, Toulouse/Almagro, 2005. Desconozco el texto exacto que ha sido utilizado.

67. Catella, Jean-Marc, Dau, Jacques, Mais qui est don(c) Quichotte?, Avignon, julio de 2000. Domina la burla a un Don Quijote excesivamente serio, que nunca consigue distinguir la realidad de la imaginación. Fue representada en el teatro «Le Petit Chien».

68. Lenturlu, Jean (textos) y Griot, Ciryl (escenificación), Le songe de Don Quichotte, mayo de 2010. Fue representada por la «Compagnie Laskar Théâtre» en el teatro «La Licorne» de Mauzun/ Puy-de-Dôme. Se trata de una adaptación con tono burlesco y contenido filosófico entorno a los conceptos de «realidad» y «sueño». Los autores derrumban certidumbres y afirmaciones de toda clase.

69. Roy, Jean Stéphane (texto) y Fleury, Simon (puesta en escena), Don Quichotte malgré lui, Montréal, octubre de 2010. Obra representada por la compañía «Possiblement Théâtre» en el «Théâtre Sainte Catherine». Inventan la entidad de la «Note», según la cual Don Quijote ha sido creado por una autora de quien se ha olvidado la historia de la literatura, y que vuelve para reivindicar la maternidad del protagonista.

70. Lecomte, Aurélie (autora y actriz), Comment je suis devenue Don Quichotte, Avignon, julio de 2011. Estrenada en el «Théâtre de l'Esperluette», esta recreación es de tono épico-burlesco; rechaza el pragmatismo y la razón, a favor de los libros y de los sueños.

71. Lippe, David, Don Qui?, Vannes, 2011. Obra de la compañía «Roi Zizo», y representada en su teatro de caballete «Zone d'Utopie Poétique».

72. Bosc, Jean-Luc, Don Quichotte(e), Charleville-Mézières, octubre de 2010. Creada por la compañía lyonesa «Voyageur Debout»; dos mujeres disfrazadas de hombre encarnan la pareja Don Quijote/ Sancho Panza. Marie-Emilie Nayrand interpreta a Don Quijo y Sandrine Gelin a Sancho Panza.

73. Cailleau, Gilles, Don Quichotte. La véritable histoire, Marsella, 2002. Obra interpretada por la compañía «Les Loups Masqués»; llamada «quasi-tragi-comédie» por el autor, la obra consta de cuatro capítulos que presentan a cuatro amigos admiradores de Don Quijote, y que creen que ha verdaderamente existido, lo cual motiva el homenaje que le rinden en el escenario. 
Quichotte» ou la folie d'aimer ${ }^{74}$ o La Complainte de la Dulcinée ${ }^{75}$; 6 títulos recalcan la esencia de caballero andante del protagonista como Don Quichotte. Souvenirs d'errance ${ }^{76}$, Le Chevalier de la Triste Figure. Don Cervantès de la Mancha ${ }^{77}$, L'incomparable aventure aventureuse du Chevalier Don Quichotte de la Mancha ${ }^{78}$, Le voyage de Don Quichotte ${ }^{79}$, o L'Homme de la Mancha ${ }^{80}$; 1 evoca la pareja como Don Quichotte et Sancho Panza ${ }^{81}, 8$ permanecen enigmáticas como Sous le ciel de Quichotte, La foire de Don Quichotte ${ }^{82}$, Les clés

74. Cain, Henri, «Don Quichotte» ou la folie d'aimer, Royan, 2010. Obra interpretada por la «Compagnie de l'Arène»; domina el tema del amor quijotesco vinculado con la locura. Destaca una completa remodelación del personaje original, no obstante, Sancho Panza conserva sus características originales, todo ello, ubicado en un contexto que, salvo los molinos de viento, poco comparte con la novela cervantina. Algunos tramos del texto cantado son sin embargo traslado del texto original.

75. Langfelder, Dulcinée (texto) y Ronfard, Alice (puesta en escena), La Complainte de la Dulcinée, Québec, abril de 2011. Fue representada en la «Salle Pierrette Gaudreault» y enaltece al personaje de Dulcinea; las autoras le dieron la palabra al personaje de quien siempre se habla pero a la que nunca se ve. Dulcinea echa de menos el haber ignorado que Don Quijote le amaba y el no haberle conocido. Esta obra implica a todos en el escenario: técnicos, decoradores, etc. acaban desempeñando un papel en la obra, como para mejor sentir la creación y poder cumplir su parte técnica. La obra aborda temas como el amor, la guerra, la religión, la sexualidad y la sociedad, sin que haya verdadera estructura, siendo el hilo conductor la asociación de ideas y el personaje de Dulcinea.

76. Sterne, Delphylne, Don Quichotte. Souvenirs d'errance, Paris, noviembre-diciembre de 2003. Representada en el teatro «Les Déchargeurs»; la autora se niega en renunciar a la imaginación, y afirma la supremacía del sueño sobre la realidad.

77. Franceschi, Luca, Le Chevalier de la Triste Figure. Don Cervantès de la Mancha, Montpellier, enero del 2002. Obra interpretada en el «Théâtre Jean Vilar».

78. Martin, Olivier (puesta en escena) y Vallot, Juliette (cantos), L'incomparable aventure aventureuse du Chevalier Don Quichotte de la Mancha, La Réunion, abril de 2010. Interpretada por la Compagnie Heyoka en el «Théâtre sous les Arbres au Port».

79. «Le Collectif des Baltringues», Le voyage de Don Quichotte, Bruxelas, agosto de 2008. Representada en la $2^{\text {a }}$ edición del «Festival Théâtres Nomades».

80. Wassermann, Dale, Leight, Mitch y Darion, Joe, L'Homme de la Mancha, Toulouse, mayo del 2010. Obra interpretada en el «Théâtre du Capitole»; lleva el mismo título que la obra de la compañía «Les anciens du Corbu», que interpretó la suya en el «Théâtre de Poissy» en la región parisina: se trata de una adaptación intergenérica de Marie-Béatrice di Savona, de abril de 2011, con magia, teatro mucical y música clásica.

81. Létuvé, Mathieu y Mellier, Marie, Don Quichotte et Sancho Panza, Normandía, 2004. Interpretada por la compañía «Caliband Théâtre», esta obra está centrada en las andanzas literarias y ontológicas del protagonista, con meta de una reflexión sobre la identidad, y ello, a partir del tema del doble.

82. Durocher, Bruno, La foire de Don Quichotte, París, junio de 2010. Estrenada en el «Théâtre Mouffetard»; a través del personaje de Don Quijote, la obra escenifica la vida del poeta polaco Bronislaw Kaminski, detenido por los nazíes en Gdansk, y encerrado seis años en el campo de Mathausen. Su obra La Foire de Don Quichotte, estrenada en el "Théâtre Cricot», se ha perdido cuando estos acontecimientos trágicos, y Bruno Rurocher trata de reconstituirla en 2010. 
du ciel $^{83}$, L'inaccessible étoile ${ }^{84}$, Les retours de Don Quichotte ${ }^{85}$, Je m'appelle Don Quichotte ${ }^{86}$,Formidable Don Quichotte ${ }^{87}$, Don Quichotte. Solo provisoire $^{88} .3$ títulos tratan de la locura del protagonista: Brass Quichotte. Le fou a un faux pli dans la cervelle ${ }^{89}$, Don Quichotte retrouvé! ou Don Quichotte et le désenchanteur ${ }^{90}$, Don Quichotte contre l'ange bleu ${ }^{91} .1$ título ubica la obra en un contexto contemporáneo y con efoque sociocultural: Au coeur $d u$

83. Strindberg, August, Les clés du ciel, París, octubre de 2009-enero de 2010. Creación estrenada en el «Théâtre du Nord-Ouest», y en la que se mezclan personajes como San Pedro, Don Quijote, Sancho Panza, no Dulcinea sino la «Amante», Cenicienta, Pulgarcito, Romeo y Julieta. El autor crea su propia lógica, su problemática de desengaño y asombro.

84. Bosco, Antonia y Yelnik, Clémentine, L'inaccessible étoile, París, junio de 2010. Estrenada en el «Théâtre du Lierre». Antonia Bosco interpreta Don Quijote, Sancho Panza y Dulcinea; y, tras modificación del decorado, se inicia una segunda parte, musical, que retoma la recreación de Jacques Brel de 1967.

85. Baillon, Sylvie y Goulouzelle, Eric, Les retours de Don Quichotte, Amiens, junio de 2003. Obra presentada en el teatro «Le tas de sable»; mediante juegos de luces, marionetas, música y texto se interpretan pasages sacados de la novela cervantina. La intergeneridicad se justifica por el rechazo de un mundo uniformizado, y que deja cada vez menos libertad para la imaginación.

86. Genêt, Mathieu, Je m'appelle Don Quichotte, Chartres, septiembre-octubre de 2011. Obra estrenada en el «Théâtre en Pièces»; se inventan nuevos personajes, se mezclan épocas y lugares, para asimilar y modernizar el mito. M. Genêt declara que lo esencial para el Hombre es soñar y vivir su libertad, cosa que nos permite el teatro a la vez que el mito quijotesco.

87. Vintjoux, Philippe, Formidable Don Quichotte, Villeneuve de Marsan, 2010. La obra pone en escena a tres jóvenes de los que uno admira a Don Quijote, otro a Sancho Panza, mientras que el tercero se mofa de la contienda de sus dos amigos. A continuación, se lee una serie de secuencias sacadas de conocidos episodios de la novela. El número de escenas y de cuadros es modulable según el número de actores.

88. Boivin, Dominique, Don Quichotte. Solo provisoire, Tremblay, 2009-2010. En esta obra estrenada en el teatro «Louis Aragon», D. Bonvin adapta e interpreta la soledad del protagonista cervantino enfrascado en sus ensoñaciones. El personaje aparece como un laberinto en busca de ideal.

89. Bernard, Didier, Brass Quichotte. Le fou a un faux pli dans la cervelle, Albertville, abril de 2011. Obra estrenada en «La Salle de Maîstre», con música de Etienne Perruchon; el Quinteto de Cobres «Alliance» interpreta una música que actúa como hilo conductor de la vertiente dramatúrgica; la narración musical da la pauta al componente teatral, así como al de la ópera. Brass Quichotte se centra en los temas de la locura y de la muerte con tono humorístico.

90. Ficheux, Pierre, Quoniam, Bertrand y Jeanvoine, Anne, Don Quichotte retrouvé! ou Don Quichotte et le désenchanteur, Aurillac, 2007. La obra se volvió a interpretar en 2008 y 2009 en Avignon y en 2010 en el teatro «Darius Milhaud» de París: el Señor Quichana, amante de literatura, no consigue encontrar un libro que le ha pedido Dulcinea; le pide ayuda a su vecino Sacha Zampa, un técnico informático que se da cuenta de que el «Désenchanteur» ha hecho desaparecer los libros mientras se estaban digitalizando. Se trata de una reflexión acerca del estatuto digital del libro en un mundo en que Google se apodera de todo.

91. Savary, Jérôme, Don Quichotte contre l'ange bleu, París, enreo-marzo de 2008. Obra representada en el «Théâtre de Paris»; en ella se sintetizan varias obras de distintos horizontes como son el Don Quijotte de Lope de Vega, Professor Unrath de Heinrich Mann y L'ange bleu de Joseph Von Sternbergæ: en esta obra, Don Quijote deja de luchar contra enemigos imaginarios, para enfrentarse con una mujer de carne y hueso, que se toma por la reencarnación de Marlène Dietrich, creadora de revistas en el «Moulin Rose» (en la obra). 
monde. Les nouvelles aventures de Don Quichotte en Seine-Saint-Denis ${ }^{92}$. Por fin, 1 título indica claramente su estética multimedia: Don Quichotte On/Off ${ }^{93}$.

La relación personaje-actor/actriz es interesante. Alguna vez, actrices vestidas de Don Quijote encarnan el mito universal, como Quichotte de Isabelle Starkier ${ }^{94}$, en que Eva Castro desempeña los papeles de don Quijote y Sancho Panza. La autora-actriz pretende que la verdad brota de la imaginación, que la locura produce sabiduría, y vice versa; esta reescritura está basada en un diálogo, que es como una exégesis de la novela cervantina, en que se analizan temas como la enseñanza del fracaso (episodios de los molinos, del rebaño y de los galeotes), la humillación (la Duquesa de Alicia) y la sabiduría de la locura (Sancho gobernador de la isla de Barataria). La actriz se ubica dentro de un libro materializado por un gran tejido, en el que se pueden imaginar algunos pasajes novelescos; a este dispositivo escénico, le acompañan marionetas y muñecos.

Otras veces, actrices vestidas de mujer encarnan lo que acaba siendo una Doña Quijote, como en Don Quijote de la Mancha (2005) de Almudena Ruiz, que nos brinda una representación intimista del mito quijotesco alejada de los estereotipos, pues ahonda en los recovecos del personaje mediante una mujer. Durante cuarenta minutos, Céline Lebrun da una original representación quijotesca, que flota sobre una escenografía minimalista en la que debe implicarse mentalmente el espectador durante la representación ${ }^{95}$.

También Don Quichotte(e) (2010), de Jean-Luc Bosc, confía a dos mujeres representar a Don Quijote y Sancho Panza, con meta de modernizar el mito. Por fin, Antonia Bosco y Clémentine Yelnik crearon L'inaccessible étoile (2010), en que Antonia Bosco interpreta Don Quijote, Sancho Panza y Dulcinea.

92. Gatti, Armand, Au coeur du monde. Les nouvelles aventures de Don Quichotte en Seine-SaintDenis, París, mayo-junio de 2009. Se trata de un espectáculo prohibido a los mayores de treinta años, y dedicado a una juventud en busca de valores; los mayores hemos fracasado en cambiar el mundo, y el futuro se lo deben construir los jóvenes por sí solos; esta obra se representó en cinco ciudades de la Seine Saint-Denis. Se trata de la adaptación del espectáculo de 1969, creado en reacción a la muerte del llamado «Pierre Lutrin» en la obra y «Gilles Tautin» en la realidad, un estudiante de instituto que se ha muerto ahogado en el Sena a continuación de una contienda con la policía, en el 68 , en las inmediaciones de las fábricas 'Renault' de Flins. En 1969, los actores eran personas tomadas en los distintos ámbitos de una sociedad en rebelión; hoy, se trata de profesionales que escenifican las aspiraciones ante el futuro expresadas por adolescentes de distintos institutos.

93. Bailleux, Jean-Marc, Don Quichotte On/Off, La Villette, 2009. Obra estrenada en el «Théâtre D'ouble»; este texto franco-hispánico presenta a un Don Quijote andante omnubilado por lo virutal, $\mathrm{y}$, con su robot, navega por la red, luchando contra reactores nucleares que toma por fantasmas, dialogando con ejércitos de soldados niños, librando de la cárcel a trabajadores clandestinos, y ennobleciendo a varias prostitutas. Don Quijote usa aquí la lengua de los medios de comunicación, sobre los que nos incita a reflexionar. Se trata de analizar la sociedad de la mundialización, enzarzada en lo virtual y lo real.

94. Starkier, Isabelle Quichotte, París, octubre de 2011/enero de 2012. Obra representada a la vez en el «Théâtre Mouffetard» y en el «Théâtre de l'Opprimé».

95. Acerca de la necesaria implicación corpórea del espectador en el proceso de la recepción artística, ver Belting (2005: 150-160). 
Las metas de estas reescrituras se clasifican en dos categorías: en la primera, la reescritura es laboratorio de innovaciones estéticas (decorado, escenificación, estructura, originalidad de la forma dialogada y de la índole de los personajes, selección de capítulos); la segunda, se centra en un mensaje ético, siendo estos mensajes de dos categorías: unos escenifican el tema de la lucidez de la locura, y otros vacían al hidalgo de su sustancia inicial para volverlo un abanderado de los indignados o marginales.

Don Quichotte (2003) de Marjolaine Aïzpiri y Hélène Labadie ${ }^{96}$, nos brinda un Sancho y un Don Quijote hieráticos en el escenario; ubicados en un sistema de tablas que permiten colocar el decorado, tienen destrás dos pantallas donde se proyectan los delirios de Don Quijote en una, y, en la otra, la narración que está haciendo Sancho al espectador; una cinta sonora precisa en qué ámbito -realidad o ilusión- nos situamos. Otra pantalla sirve para proyectar imágenes, como la de un desnudo al óleo que sugiere a Dulcinea.

Ich bin Don Quichotte (2006) ${ }^{97}$, es una obra multimedia con música en directo, proyección de imágenes, texto, juego escénico filmado en directo y vuelto a proyectar instantáneamente a distintas velocidades; las aspas de un molino sirven de pantalla para la proyección de lo que acaba siendo los fantasmas del protagonista; la nitidez de la imagen depende de la velocidad a la que giran las aspas del molino. Se articula música clásica, rock, postrock, acústica contemporánea y dub ${ }^{98}$. Parcialmente improvisada, la música se adapta al movimiento de la «performance» de los actores. Se plantea aquí una reflexión sobre lo real y lo virtual.

En Don Quichotte On/Off (2009) ${ }^{99}$, un internauta andante lucha en la web contra centrales nucleares, se indigna ante ejércitos de niños soldados, defiende los derechos de trabajadores clandestinos, y nos brinda un mensaje de corte político y socioeconómico. Preciso que el recurso al componente mediático no induce necesariamente mensaje político: Don Quichotte retrouvé! ou Don Quichotte et le désenchanteur (2007) ${ }^{100}$ nos sume en el mundo de los libros digitalizados que, debido a un bug informático, se esfuman por la web. Aquí, la reflexión se centra en el estatuto del libro digital. Sin embargo, Au cour du monde. Les nouvelles aventures de Don Quichotte en Seine-Saint-Denis (2009) ${ }^{101}$ no disimula su intención política; el espectáculo, inicialmente creado en 1969 tras los acontecimientos del 68 francés, volvió al escenario en

96. Aïzpiri, Marjolaine y Labadie, Hélène Don Quichotte, Clamart, enero-febrero de 2003.

97. Covello, Richard (imágenes), Geghre, Mathieu (música) y Philip, Lisie (puesta en escena y coreografía), Ich bin Don Quichotte, 2006. Representado por la Compañía «Antipodes», en el «Illustre Théâtre» de Niza.

98. Tipo de música que procede del reggae jamaicano, y que resulta de la mezcla de dos cintas sonoras.

99. Bailleux, Jean-Marc, Don Quichotte On/Off, La Villette, 2009.

100. Ficheux, Pierre, Jeanvoine, Anne, Quoniam, Bertrand, Don Quichotte retrouvé! ou Don Quichotte et le désenchanteur, Aurillac, 2007.

101. Gatti, Armand, Au cœur du monde. Les nouvelles aventures de Don Quichotte en SeineSaint-Denis, Paris, 2009. 
mayo-junio de 2009, dando la impresión de que las aportaciones del 68 no han sido tan eficientes.

Don Quichotte (2007) de Philippe Adrien ${ }^{102}$, a la vez impacta más con su reivindicación, y resulta más matizado respecto a la defensa de los marginales. $\mathrm{Ph}$. Adrien moldea un personaje defensor de los marginales, pero rehusando la imagen falsamente enaltecedora de la doxa acerca del mito literario, mostrando que éste incumple su misión, incluso, actuando de modo erróneo. $\mathrm{Ph}$. Adrien desengaña al público acerca de un personaje a su vez engañado; investiga la razón por la cual los S.D.F. parisienses se autodefinieron «Les enfants de Don Quichotte», vinculando así una situación socioeconómica contemporánea con un mito universal. La puesta en escena propone un espacio circular en que se sitúan los actores y, en una pantalla ubicada en el fondo del escenario, se proyectan imágenes de «Les enfants de Don Quichotte» del Canal Saint Martin, imágenes que se articulan con otras de Velázquez y Goya. Las máscaras de carácter grotesco y las muecas de los actores provocan un desfase con las imágenes de la realidad socioeconómica proyectadas en la pantalla. La sociedad francesa aparece como responsable de lo esperpéntico visto en la pantalla.

En cuanto a personages, la presencia de Don Quijote en estas obras es desigual. En la mayoría de los casos actúa desde el principio de la representación, compartiendo el papel de motor dramatúrgico con Sancho, como en Don Quichotte et Sancho Panza, donde se trata el tema del «doble». En otras obras, el protagonista es mero soporte de una investigación en texto y lenguage teatrales, como en Don Quichotte de Jean-Pierre Jourdain (2010) ${ }^{103}$. Arrancando de Jean Canavaggio y de Michel Foucault, J-P. Jourdain considera la novela cervantina como una organización de signos que se mueven en un ámbito mental. Trasladar la novela cervantina al teatro, es para J-P. Jourdain una manera de subrayar la supremacía de los signos por encima de los géneros. Lo que le interesa a J-P. Jourdain es el poder de la literatura por encima del espacio, tiempo, culturas y géneros; para ello, escenifica los ocho primeros capítulos de los ciento veinticuatro de la novela, utilizando el mito cervantino como pretexto a unas investigaciones dramatúrgicas, en las que el actor quijotesco acaba criticando las distintas modalidades según las que sus compañeros actores desempeñan el papel teatral que les corresponde. A veces, le ocurre a Don Quijote en el teatro lo que a Dulcinea en la novela: es

102. Adrien, Philippe, Don Quichotte, París, 11 de septiembre - 14 de octubre del 2007. La obra se estrenó en el «Théâtre de la Tempête», puesta en escena por Philippe Adrien, que capitanea la «Compagnie du $3^{\mathrm{e}}$ œil»; Philippe Adrien dirige desde 1996 el citado teatro, y también es profesor en el «Conservatoir National Superieur d'Art Dramatique de Paris»; su estilo en forma de «farsa paranoiaca» reivindica cierta brutalidad, violencia e implicación del público.

103. Jourdain, Jean-Pierre Don Quichotte, Lyon, diciembre del 2010. Obra estrenada en el «Théâtre National Populaire», con texto de J-P. Jourdain y escenificación de Christian Schiaretti, a partir de una traducción de Jean-Raymond Fanlo. Según J-P. Jourdain «Don Quijote no es un personaje, es un libro, un libro que habla» («Don Quichotte n'est pas un personnage. C'est un livre. Un livre qui parle»). 
una presencia ausente, como en La Complainte de la Dulcinée, en que Don Quijote pierde liderazgo para enaltecer la figura de Dulcinea; la autora-actora declaraba «darle el derecho de palabra a esa Dulcinea que está presente en cada página del Don Quijote pero a la que nunca se ve. En su intento de salvar al mundo, Don Quijote está motivado primero por esa Dulcinea y quiere mostrar que existe y que incluso está en cada uno de nosotros ${ }^{104}$.

Pocas obras muestran la muerte de Don Quijote, y, cuando acontece, los autores suelen presentar a un protagonista conmovedor, como en la comedia musical L'Homme de la Mancha (2010) de Didier Benetti ${ }^{105}$, o Don Quichotte (2010) de Thibaut Radomme y Laurent Pelly ${ }^{106}$. Las obras que tratan en tono burlesco de la muerte del héroe son menos numerosas, como Brass Quichotte. Le fou a un faux pli dans la cervelle de Didier Bernard, que no discrimina entre vida y muerte de Don Quijote.

Destacaré tres categorías de recreaciones en cuanto a espacio y tiempo: las que trasladan al espectador al siglo XVII, como Don Quichotte de Jean Petrement en 2011 ${ }^{107}$, las que trasladan Don Quijote a los siglos XX y XXI, como Don Quichotte de Philippe Adrien, Au cour du monde. Les nouvelles aventures de Don Quichotte en Seine-Saint-Denis o Don Quichotte On/Off; por fin, están las que confunden tiempo y espacio, como Les clés du ciel de August Strindberg o Don Quichotte a la plancha de Michel Crance.

\section{CONCLUSIONES}

Como libro abierto, el Quijote implica recreación; como potencial dramatúrgico, genera recreación teatral. Tras las satíricas españoladas de Pichou, la trilogía de Guérin de Bouscal ahondará en el fenómeno de recreación con sólidos intentos estéticos y éticos, que abrirán paso a obras de la segunda mitad del siglo XVIII en las que, sin dejar la tonalidad burlesca, se le dará un enfoque más filosófico a la locura de Don Quijote. La revolución francesa marca un giro en las representaciones de Don Quijote, y el romanticismo engalanará por primera vez al personaje con una dimensión humana de la que

104. «J'ai décidé de donner le droit de parole à cette Dulcinée qui est présente à chaque page de Don Quichotte mais qu'on ne voit jamais. Dans sa tentative de sauver le monde, Don Quichotte est d'abord motivé par cette Dulcinée et je veux montrer qu'elle existe et qu'elle est même en chacun de nous», Arts de la scène, http://www.voir.ca/publishing/article.aspx?zone=6\&section=8\&article=76657.

105. Benetti, Didier, L’Homme de la Mancha, Monte-Carlo, 2010.

106. Pelly, Laurent y Radomme, Thibaut Don Quichotte, Bruxelles, 2010. La obra fue representada en la Ópera «La Monnaie».

107. Petrement, Jean, Don Quichotte, Avignon, 2011. J. Petrement es director artístico de la «Compagnie Bacchus» de Besançon, que representó su espectáculo en el «Théâtre des Ombrages» de Montfavet. Esta adaptación nos traslada al siglo XVII, y se centra en las andanzas de un picaresco Don Quijote, que debe sufrir la censura inquisitorial. Se trata de una representación teatral en un anfiteatro de 250 butacas, con dispositivo técnico muy elaborado que implica decorado, imagen, luz y sonido. 
venía desprovisto en las representacines galas. Llama la atención que las obras serán cada vez más numerosas e intergenéricas en este último decenio galo.

Recrear no puede ser sino producir una obra singular que responda a los códigos específicos del género teatral; vimos que el siglo XXI ultramontano propone recreaciones quijotescas que ensanchan los límites de las artes escénicas, aportando nuevos potenciales de representación dramatúrgica, que enriquece la recreación quijotesca con los recursos de la intergenericidad y de la transescritura.

La cuestión de la lengua ya no es tan vigente como pudo serlo en el pasado; la difusión del español estas últimas décadas cambia el modo de recepción del Quijote, lo cual influye en el fenómeno de recreación; incluso hemos registrado recreaciones bilingües ${ }^{108}$ que muestran una evolución en los mecanismos de la transculturalidad.

Las innovaciones estéticas y éticas del siglo XXI son las huellas de un contexto cultural, político y socioeconómico con valores por definir. Estas recreaciones quijotescas son intentos narcisistas, para hallar una nueva ruta para los próximos decenios. Recreación y vida parecen pues indisociables, como ya, en tiempos de Cervantes: l'histoire continue...

\section{BIBLIOGRAFÍA}

Babelon, Jean (1929). L'ingénieux hidalgo Don Quichotte de la Manche. Paris: La Cité des Livres.

Bady, Vincent (1992). Quijotypanza. en Claude Labère (1998). Don Quichotte théâtralisé au XX $X^{\mathrm{e}}$ siècle, Sous la direction du Professeur Andrée Mansau. Toulouse: Université de Toulouse-Le Mirail (Toulouse II), vol. III, pp. 604-651.

Bardon, Maurice (1931). «Don Quichotte» en France au XVII et au XVIII siècles. 16051815. Paris: Champion, 2 vols.

Belting, Hans (2005). La vraie image. Croire aux images?, Jean Torrent (Trad.). Paris: Éditions Gallimard.

Berdot, Georges (1989). L'ingénieux hidalgo Don Quichotte de la Manche. en Claude Labère (1998). Don Quichotte théâtralisé au XX $\mathrm{XX}^{\mathrm{e}}$ siècle, Sous la direction du Professeur Andrée Mansau. Toulouse: Université de Toulouse-Le Mirail (Toulouse II), vol. III, pp. 652-725.

Biancolelli, Pierre-François (1753). Arlequin toujours Arlequin. Paris: Briasson.

Boismortier, Joseph Bodin de (1743). Don Quichotte chez la duchesse, Ballet comique en trois actes, Livret de Charles-Simon Favart. Paris: Roger Blanchard.

Bosc, Jean-Luc (1993). Don Quichotte, s.e.

Brel, Jacques (1968). L'Homme de la Mancha, s.e.

Caldicott, C. E. J. (1979). «The Trilogy of Guerin de Bouscal: A Phase in the Progression from Dom Quixote to Molière's Don Juan», The Modern Lenguage Review, 74, 3, pp. 553-571.

108. El fenómeno, sin embargo, no me parece totalmente nuevo, aunque se vaya confirmando en el siglo XXI; en efecto, recuerdo que queda por resolver en qué medida Molière no ha tomado, por lo menos parcialmente, el texto original en el momento de sus recreaciones quijotescas. 
Caldicott, C. E. J. (1981). Le gouvernement de Sanche Pansa. Genève: Droz.

Campistron, Jean Galbert (1710). Le Jaloux désabusé. La Haye: J. Clos.

Canavaggio, Jean (2001). Cervantès, «Don Quichotte» précédé de "La Galatée». Oeuvres romanesques complètes I. Paris: Gallimard, Bibliothèque de La Pléiade, $\mathrm{n}^{\circ} 18$.

Cassou, Jean (ed.) (1949). Cervantes, L'ingénieux hidalgo Don Quichotte de la Manche. Nouvelles exemplaires, textes traduits par Jean Cassou, César Oudin et François Rosset [sic.], présentation et annotation de Jean Cassou. Paris: Gallimard, Bibliothèque de La Pléiade, . $^{\circ} 18$.

Cioranescu, Alexandre (1983). Le masque et le visage. Du baroque espagnol au classicisme français. Genève: Droz.

Couderc, Christophe (2007). «Don Quichotte et Sanche sur la scène française (XVIIe et XVIIIe siècles)», en Cervantès et la France / Cervantes y Francia. Mélanges de la Casa de Velázquez, Jean Canavaggio (Coord.). Madrid: Casa de Velázquez, Nouvelle série, Tome 37 (2), pp. 33-50.

Crooks, Esther J. (1932). «The influence of Cervantes in France in the seventeeth century», The Johns Hopkins Studies in Romance Liiteratures and Languages, Extra volume IV.

Destouches, Philippe (1718). Le Curieux impertinent. Paris: François Le Breton.

Fabre d'Églantine, Philippe François Nazaire (1791). Le Philinte de Molière, ou La suite $d u$ Misanthrope, Comédie en 5 actes et en vers, par P. F. N. Fabre d'Eglantine, à Paris, au Théâtre-français, le 22 février 1790. Paris: Imprimerie de Prault.

Filleau de Saint-Martin, François (1678). Histoire de l'Admirable Don Quichotte de la Manche, traduite de l'espagnol par Filleau de Saint-Martin. Paris: Claude Barbin.

Florian, Jean-Pierre Claris de (1792). «Don Quichotte», Fables. Paris: P. Didot l'Aîné.

Fuzelier, Louis (1711). Arlequin et Scaramouche vendangeurs, Divertissement. Précédé d'un prologue, et suivi de Pierrot Sancho Pansa gouverneur de l'Isle Barataria, Éxécuté au grand jeu du préau de la foire S. Laurent au mois de septembre 1710. Paris: s.e.

Galas, Didier (2005). Ficción/Quijote, s.e.

Guérin de Bouscal, Guyon (1642). Le gouvernement de Sanche Pansa. Paris: Antoine de Sommaville et Augustin Courbé.

Guérin de Bouscal, Guyon (1979). Dom Quixote de la Manche, Édition de Daniela Dalla Valle et Amédée Carriat. Genève-Paris: Slatkine-Champion.

Guérin de Bouscal, Guyon (1986). Dom Quichot de la Manche. Seconde partie, Fac-similé de l'édition de 1640, Par Marie-Lyne Akhamlich. Toulouse: Centre XVII ${ }^{\mathrm{e}}$ siècle «Idées, thèmes et formes».

Hazard, Paul (1931). «Don Quichotte» de Cervantès. Étude et analyse. Paris: Mellotée.

Joxe, François (1991). Don Quichotte. s.e.

Labère, Claude (1998). Don Quichotte théâtralisé au XXe siècle, Sous la direction du Professeur Andrée Mansau. Toulouse: Université de Toulouse-Le Mirail (Toulouse II), 3 vols.

Laya, M. (1824). L'Ami des Lois, Comédie en 5 actes, Représentée pour la première fois sur le Théâtre français, le 2 janvier 1793. Paris: Veuve Dabo.

Lefebvre, Maryse (1993). Quichotte en Claude Labère (1998). Don Quichotte théâtralisé au XXe siècle, Sous la direction du Professeur Andrée Mansau. Toulouse: Université de Toulouse-Le Mirail (Toulouse II), vol. III, pp. 801-843.

Leroy, Jean-Pierre (1989). Pichou, Les folies (...) Texte établi et présenté par Genève. Paris: Droz.

Massenet, Jules (1910). Don Quichotte. Comédie hérö̈que en cinq actes. Paris: Heugel \& Cie, última edición Paris, A. Leduc, 2007.

Miomandre, Francis de (Trad.) (1935b). Don Quichotte de la Manche. Paris: Union Latine d'Editions. 
Moner, Michel (2004). «La recepción de Don Quijote en Francia», El Español en el Mundo. Anuario del Instituto Cervantes. 7, pp. 39-56.

Neumann, Max-Helmut (1930). «Cervantes werke in Frankreich», Revue Hispanique, LXXVIII, pp. 1-309.

Nougaret, Pierre Jean-Baptiste (1763). Sancho gouverneur. s.e.

Oudin, César (trad.) (1614). Michel de Cervantes, Don Quixote de la Manche [.]. Paris: Jean Fouët.

Paxinou, Nele (1992). Don Quichotte, en Claude Labère (1998). Don Quichotte théâtralisé au $X X^{e}$ siècle, Sous la direction du Professeur Andrée Mansau. Toulouse: Université de Toulouse-Le Mirail (Toulouse II), vol. III, pp. 844-912.

Plana, Muriel (2004). Roman, théâtre, cinéma: adaptations, hybridations et dialogue des arts. Rosny-sous-Bois: Muriel Plana-Bréal.

Poinsinet, Antoine Alexandre Henri (1762). Sancho Pança dans son île, Opéra bouffon en 1 acte, Représenté devant Leurs Majestés à Fontainebleau, le 20 octobre 1762, par les Comédiens italiens. Paris: C. Ballard.

Pompejano Natoli, Valeria (1994). «Il "Quichottisme" nella litteratura francese preclassica. Situazione e prospettive della critica», Seincento francese oggi. Situazione e prospettive della ricerca, G. Dotoli (coord.). Bari-Paris: Adriatica-Nizet, pp. 233-258.

Richepin, Jean (1905). Don Quichotte. Drame héroï-comique en vers, en trois parties et huit tableaux. Paris: Comédie Française.

Robert, Marthe (1963). L'ancien et le nouveau. De Don Quichotte à Franz Kafka. Paris: Bernard Grasset.

Rosset, François de (trad.) (1618). Michel de Cervantes, Seconde Partie de l'Histoire de l'ingénieux et redoutable chevalier Don Quixote de la Manche [.]. Paris: Veuve Jacques de Clou \& Denis Moreau.

Sardou, Victorien (1864). Don Quichotte, Pièce en trois actes et huit tableaux. Paris: Michel-Lévy frères.

Schulman, Aline (trad.) (1997). Miguel de Cervantes, L'ingénieux hidalgo Don Quichotte de la Manche, Préface de Jean-Claude Chevalier. Paris: Éditions du Seuil.

Shelton, Thomas (1612). The History of the Valorous \& Witty Knight-Errant Don Quixote of the Mancha. Londres: Blount \& Barret.

Thierry y Gillier, Jean-Claude (1727). Sancho Pança gouverneur, ou La bagatelle, Opéra comique en deux actes. Foire Saint-Laurent: s.e.

Viardot, Louis (trad.) (1836-1837). Michel de Cervantes, L'ingénieux hidalgo Don Quichotte de la Manche. Paris: J.J. Dubochet et Cie.

\section{BIBLIOGRAFÍA AÑADIDA}

Abbrugiati, Raymond (2000). Du genre narratif à l'opéra au théâtre et au cinéma, (Actes des Journées d'étude de 1999 organisées par R. Abbrugiati et le C.I.R.I.L.L.I.S), Raymond Abbrugiati (Dir.). Toulouse/Talence: Université de Toulouse-Le Mirail/Centre interuniversitaire de recherches sur l'Italie.

Albrecht-Crane, Christa y Cutchins, Dennis (2010). Adaptation Studies: New Approaches. Madison (N.J.): Fairleigh Dickinson University Press.

Arellano, Ignacio, Cervantes y la cultura visual del Barroco, en preparación.

Arellano, Ignacio (2007). Don Quijote en el teatro español: del Siglo de Oro al siglo XX, Madrid: Visor Libros.

Bruneel, Pierre (2006). Don Quichotte et le roman malgré lui. Paris: Klincksieck. 
Canavaggio, Jean (1986). Cervantès. Paris: Éditions Fayard.

Canavaggio, Jean (2005). Don Quichotte, du livre au mythe: quatre siècles d'errance, Paris: Fayard.

Couderc, Christophe (2011). Le théâtre espagnol du Siècle d'Or en France (XVII ${ }^{e-X X}$ siècles). De la traduction au transfert culturel. Actes de colloque à paraître aux Presses Universitaires de Paris Ouest, Collection Littérature et Poétique comparées.

Farcy, Gérard-Denis y BUTEL, Yannick (2000). L'adaptation théâtrale, entre obsolescence et résistance. Caen: C.R.E.D.A.S. (Centre de recherches et de documentation des arts du spectacle).

Fine, Ruth, López Navia, Santiago (Dir.) (2008). Cervantes y las religiones, (Actas del Coloquio Internacional de la Asociación de Cervantistas, Universidad Hebrea de Jerusalén, Israel, 19-21 de diciembre de 2005). Madrid: Iberoamericana.

Gaudreault, André, Groensteen, Thierry (Dir.) (1999). La transécriture: pour une théorie de l'adaptation (Littérature, cinéma, bande dessinée, théâtre, clip ). Actes du Colloque de Cerisy de 14-21 août 1993. Québec/Angoulême: Centre national de la bande dessinée.

Hutcheon, Linda (2006). A theory of Adaptation. New York/London: Routledge.

Insúa Cereceda, Mariela, Mata Indurain, Carlos (2006). El «Quijote»: Miguel de Cervantes. Berriozar: Cénlit Ediciones.

Martínez Mata, Emilio (2007). Cervantes y el Quijote. Actas del Coloquio Internacional de Oviedo 27 a 30 de octubre de 2004. Madrid: Arco libros.

Perrot, Danielle (Coord.) (2003). Don Quichotte au XXe siècle. Réceptions d'une figure mythique dans la littérature et les arts. Clermont-Ferrand: Université Blaise Pascal.

Rico, Francisco (2005). El texto del «Quijote». Preliminares a una ecdótica del Siglo de Oro. Barcelona: Destino.

Stanislav, Zimic (1992). El teatro de Cervantes. Madrid: Castalia.

Torrione, Margarita (2009), «L'Espagne dans l'éducation des enfants de France: Don Quichotte, le miles gloriosus de Philippe d'Anjou, 1693», en ¿Louis XIV espagnol? Madrid et Versailles, images et modèles, Margarita Torrione \& Gérard Sabatier (coords.). Paris: Éditions de la Maison des Sciences de l'Homme \& Centre de Recherche du Château de Versailles, Collection «Aulica», pp. 271-287, il. color.

Torrione, Margarita (2005), «El Carnaval de 1700 en la Corte de Luis XIV», Reales Sitios, Revista del Patrimonio Nacional, $\mathrm{n}^{\circ} 166$, pp. 42- 61, il. color.

Torrione, Margarita (2005), «El Quijote en la educación de Felipe V» / «Don Quixote in Philip V's education», en Don Quijote. Tapices españoles del siglo XVIII / Don Quixote. 18th Century Spanish tapestries, Catálogo bilingüe de la exposición, Meadows Museum (Dallas) y Museo de Santa Cruz (Toledo). Madrid: Ministerio de Cultura, Ministerio de Asuntos Exteriores, Patrimonio Nacional, SEACEX, pp. 89-118, il. color. Wasiolka, Joëlle (2009). Genres en mouvements. Paris: Nouveau Monde. 


\section{ANEJO}

\section{Lista de las 59 obras del corpus}

\begin{tabular}{|c|c|c|c|}
\hline AUTOR & TÍTULO & LUGAR & FECHA \\
\hline «Compagnie de l'Arène» & «Don Quichotte» ou la folie d'aimer & Royan & $11 / 2010$ \\
\hline «Le Collectif des Baltringues» & Le voyage de Don Quichotte & Bruxelas & $8 / 2008$ \\
\hline «Les anciens du Corbu» & L'homme de la Mancha109 & Poissy & $5 / 2010$ \\
\hline Adrien, Philippe & Don Quichotte & París & $9-10 / 2007$ \\
\hline $\begin{array}{l}\text { Aïzpiri, Marjolaine } \\
\text { Labadie, Hélène }\end{array}$ & Don Quichotte & Clamart & $1-2 / 2003$ \\
\hline Bailleux, Jean-Marc & Don Quichotte On/Off ${ }^{110}$ & La Villette & 2009 \\
\hline $\begin{array}{l}\text { Baillon, Sylvie } \\
\text { Goulouzelle, Eric }\end{array}$ & Les retours de Don Quichotte & Amiens & $6 / 2003$ \\
\hline Ballue, Jacques & Don Quichotte ${ }^{111}$ & Agen & $4 / 2010$ \\
\hline Benetti, Didier & L'Homme de la Mancha & Monte-Carlo & 2010 \\
\hline Berdot, Georges & $\begin{array}{l}\text { L'ingénieux hidalgo Don Quichotte } \\
\text { de la Manche }\end{array}$ & Burdeos & 1989 \\
\hline $\begin{array}{l}\text { Bernard, Didier } \\
\text { Perruchon, Étienne }\end{array}$ & $\begin{array}{l}\text { Brass Quichotte. Le fou a un faux } \\
\text { pli dans la cervelle }\end{array}$ & Albertville & $4 / 2011$ \\
\hline Boivin, Dominique & Don Quichotte. Solo provisoire & Tremblay & 2009-2010 \\
\hline Bonnin, Romin & Sous le ciel de Quichotte & Nîmes & $11 / 2005$ \\
\hline Bosc, Jean-Luc & Don Quichotte(e) & $\begin{array}{l}\text { Charleville- } \\
\text { Mézières }\end{array}$ & $10 / 2010$ \\
\hline $\begin{array}{l}\text { Bosco, Antonia } \\
\text { Yelnik, Clémentine }\end{array}$ & L'inaccessible étoile & París & $6 / 2010$ \\
\hline $\begin{array}{l}\text { Brel, Jacques } \\
\text { Chambre, Gérard }\end{array}$ & L'Homme de la Mancha ${ }^{112}$ & París & $\begin{array}{l}5 / 2008- \\
1 / 2009\end{array}$ \\
\hline Cailleau, Gilles & Don Quichotte. La véritable histoire & Marsella & 2002 \\
\hline Cain, Henri & «Don Quichotte» ou la folie d'aimer & Royan & 2010 \\
\hline
\end{tabular}

109. Estrenada en el «Théâtre de Poissy»-región parisina-, esta obra intergenérica articula el espectaculo de magia, la música clásica y el teatro mucical.

110. Obra representada en el «Théâtre D’ouble»; aquí, Don Quijote nos invita a reflexionar sobre el sentido de la noción de «comunicación» en nuestra época; se analiza una sociedad del mundialismo, enzarzada en unos medios de comunicación que no siempren distinguen lo virtual de lo real. Cuando la segunda edición de «Recontres Européennes de Théâtre», que tuvo lugar en el «Théâtre des Célestins» de Lyon, esta obra fue ocasión de un debate público titulado: «La réécriture de Don Quichotte à l'heure de l'Internet. Pour revisiter les frontières entre réel et virtuel...».

111. La obra se estrenó en el «Théâtre Ducourneau» el 17 de abril. Se trata de una creación francesa, pero en lengua española, y con acompañamiento musical y visual.

112. El texto de Jacques Brel, reescrito por G. Chambre, fue representado en varios teatros parisinos como el «Espace Pierre Cardin» o el teatro de «L'Entrepôt», e involucra a actores, bailarines, cantantes y músicos, con obvia riqueza de decorados y trajes. 


\begin{tabular}{|l|l|l|l|}
\hline $\begin{array}{l}\text { Catella, Jean-Marc } \\
\text { Dau, Jacques }\end{array}$ & Mais qui est don(c) Quichotte? & Avignon & $7 / 2000$ \\
\hline Compañ́a «Mattagumber» & Don Quichotte & $\begin{array}{l}\text { Mooslargue } \\
\text { (Alsacia) }\end{array}$ & $8 / 2011$ \\
\hline $\begin{array}{l}\text { Covello, Richard (imágenes) } \\
\text { Geghre, Mathieu (música) } \\
\text { Philip, Lisie (escenificación y } \\
\text { coregrafía) }\end{array}$ & Ich bin Don Quichotte & Niza & $5 / 2006$ \\
\hline Crance, Michel & Don Quichotte à la plancha & Chartres & $6 / 2010$ \\
\hline $\begin{array}{l}\text { Darion, Joe } \\
\text { Leight, Mitch } \\
\text { Wassermann, Dale }\end{array}$ & L'Homme de la Mancha & Toulouse & $5 / 2010$ \\
\hline $\begin{array}{l}\text { Delcroix, Didier } \\
\text { Dogbé, Alfred }\end{array}$ & Don Quichotte 113 & $\begin{array}{l}\text { Certy-Pon- } \\
\text { toise }\end{array}$ & $3 / 2006$ \\
\hline Durocher, Bruno & Don Quichotte & Níger & 1997 \\
\hline Flotats, José Maria & La foire de Don Quichotte & París & $6 / 2010$ \\
\hline Franceschi, Luca & Les Musiques de Don Quichotte & Ambronay & $9 / 2005$ \\
\hline Franceschi, Luca & $\begin{array}{l}\text { Le Chevalier de la Triste Figure. } \\
\text { Don Cervantès de la Mancha }\end{array}$ & Montpellier & $1 / 2002$ \\
\hline Galas, Didier & $\begin{array}{l}\text { Le Chevalier de la Triste Figure. } \\
\text { Don Cervantès de la Mancha }\end{array}$ & Montpellier & 2002 \\
\hline Gatti, Armand & Ficción/Quijote & Caracas & 2005 \\
\hline Gauzeran, Christophe & $\begin{array}{l}\text { Au coeur du monde. Les nouvelles } \\
\text { aventures de Don Quichotte en } \\
\text { Seine-Saint-Denis }\end{array}$ & París & $5-6 / 2009$ \\
\hline Don Quichotte 115 & París & $9-10 / 2008$ \\
\hline
\end{tabular}

113. Obra representada en el teatro «Uvol», con busca exclusiva de efecto cómico, mediante los resursos del «arte povera»; esta creación está desprovista de intención semiótica, pues estudia efectos cómicos de tipo escénico; unos personajes aficionados de Don Quijote se disfrazan burdamente, para encarnar a su ídolo; en cuanto a decorado, una hace de Rocinante y otro mango sirve de lanza, mientras la mula de Sancho Panza es un caballo de plástico con ruedas; los molinos de viento son personajes tomados en el público y subidos al escenario, donde mueven los brazos como si fuesen molinos; se representa también el episodio del caballero de los espejos y del rebaño de ovejas.

114. Obra representada en el «Théâtre Jean Vilar».

115. Christophe Gauzeran pertenece a la compañía «Farenheit 451», que estrenó la adaptación en el «Vingtième Théâtre», ubicado en París; se inspira Ch. Cauzeran de la primeriza adaptación de 1640, de Daniel Guérin de Bouscal. Se trata de un teatro circense, con juego de luces, maromas, máscaras, música, tejidos y trapecios; la obra se centra en la segunda parte de la novela cervantina. Es un teatro de tipo «comedie française», estilo Farsa o Commedia dell'arte, que linda con lo fantástico, como para escenificar los sueños y locuras de Don Quijote, centro del espectáculo. Se trata de materializar, de manera poética e intergenérica, los sueños de Don Quijote en tres dimensiones. Ch. Gauzeran declara que «tras esta mascarada que plantea el mundo de ilusiones propuestas al Caballero, exploramos el mundo tal y como lo ve Don Quijote. Un mundo poblado de gigantes y hechiceros. Entonces, volcaremos en un universo más onírico confiado a gente circense para poner en escena los sueños del Hidalgo» («après cette mascarade qui met en place le monde d'illusions proposées au Chevalier, nous explorerons le monde tel que le voit Don Quichotte. Un monde peuplé de géants et d'enchanteurs. Là, nous basculerons dans un univers plus onirique confié aux circassiens pour mettre en scène les rêves de l'Hidalgo...»), Les Trois coups, http://lestroiscoups.over-blog.com/article-22236395.html. 


\begin{tabular}{|c|c|c|c|}
\hline Genêt, Mathieu & Je m'appelle Don Quichotte & Chartres & $9-10 / 2011$ \\
\hline Gery, David & Don Quichotte 116 & París & $9-10 / 2009$ \\
\hline $\begin{array}{l}\text { Griot, Cyril (puesta en escena) } \\
\text { Lenturlu, Jean (textos) }\end{array}$ & Le songe de Don Quichotte ${ }^{117}$ & Mauzun & $5 / 2010$ \\
\hline $\begin{array}{l}\text { Jeanvoine, Anne } \\
\text { Ficheux, Pierre } \\
\text { Quoniam, Bertrand }\end{array}$ & $\begin{array}{l}\text { Don Quichotte retrouvé! ou Don } \\
\text { Quichotte et le désenchanteur }{ }^{118}\end{array}$ & Aurillac & 2007 \\
\hline $\begin{array}{l}\text { Jourdain, Jean-Pierre } \\
\text { Schiaretti, Christian }\end{array}$ & Don Quichotte & Lyon & $12 / 2010$ \\
\hline $\begin{array}{l}\text { Langfelder, Dulcinée (texto) } \\
\text { Ronfard, Alice (escenifica- } \\
\text { ción) }\end{array}$ & La Complainte de la Dulcinée & Québec & $4 / 2011$ \\
\hline Lecomte, Aurélie & $\begin{array}{l}\text { Comment je suis devenue Don } \\
\text { Quichotte }\end{array}$ & Avignon & $6 / 2011$ \\
\hline $\begin{array}{l}\text { Lenturlu, Jean (textos) } \\
\text { Griot, Ciryl (escenificación) }\end{array}$ & Le songe de Don Quichotte, & Mauzun & $5 / 2010$ \\
\hline Lethé, Georges & Mais qui est Don Quichotte & Villerbanne & 2002 \\
\hline $\begin{array}{l}\text { Létuvé, Mathieu y Mellier, } \\
\text { Marie }\end{array}$ & Don Quichotte et Sancho Panza & Normandia & 2004 \\
\hline Lippe, David & Don Qui? & Vannes & 2011 \\
\hline $\begin{array}{l}\text { Pelly, Laurent } \\
\text { Radomme, Thibault }\end{array}$ & Don Quichotte & Bruxelas & 2010 \\
\hline Pétrement, Jean & Don Quichotte & Avignon & 2011 \\
\hline $\begin{array}{l}\text { Quoniam, Bertrand } \\
\text { Steinfor, Jean-Michel }\end{array}$ & $\begin{array}{l}\text { Don Quichotte et le Désenchan- } \\
\text { teur }^{119}\end{array}$ & París & $1 / 2010$ \\
\hline $\begin{array}{l}\text { Robb, Bruyère } \\
\text { Agazar, Jean-Pierre }\end{array}$ & Don Quichotte ${ }^{120}$ & Lavaur & $7 / 2008$ \\
\hline $\begin{array}{l}\text { Roy, Jean Stéphane (texto) } \\
\text { Fleury, Simon (escenificación) }\end{array}$ & Don Quichotte malgré lui & Montreal & $10 / 2010$ \\
\hline Ruiz, Almudena & Don Quijote de la Mancha & Almagro & 2005 \\
\hline Savary, Jérôme & Don Quichotte contre l'ange bleu ${ }^{121}$ & París & $1-3 / 2008$ \\
\hline
\end{tabular}

116. La obra fue estrenada en el «Théâtre de l'île Saint-Louis»; se trata de una adaptación en cinco actos del poema de Henri Cain; la adaptación que hace D. Géry es muy intimista, pues el público está prácticamente en contacto con los personajes, como si se mezclasen el espacio de la ficción teatral y el de la sala. Alternan momentos de texto cantado y hablado, con escasez de coros e instrumentos músicos. La orientaciónn patética de la adaptación es patente en la muerte de Don Quijote, momento de dramatismo lírico.

117. Ha sido la «Compagnie Laskar Théâtre» la que representó esta obra en el teatro «La Licorne», ubicado en la región del Puy-de-Dôme. Se trata de teatro de payasos («théâtre clownesque»), de corte burlesco, pero que plantea una reflexión filosófica acerca de qué son la realidad y el sueño. Con tono humorístico y cómico, esta obra derrumba certidumbres, creencias, y dogmas de todo tipo.

118. Esta obra de 2007, también se interpretó en 2008 y 2009 en Avignon, y, en el 2010, se volvió a representar en el teatro «Darius Milhaud» de París.

119. Obra estrenada en el «Théâtre Darius Milhaud».

120. Obra representada en el «Théâtre de l'Improviste», en la région Tarn/Midi-Pyrénnées.

121. Obra estrenada en el «Théâtre de Paris», con Ariel Dombasle y los actores de «La Boîte à Rêves». 


\begin{tabular}{|c|c|c|c|}
\hline Savona, Marie-Béatrice di & L'Homme de la Mancha & & $4 / 2011$ \\
\hline Schepens, Peggy & Don Quichotte ${ }^{122}$ & París & $3 / 2005$ \\
\hline Starkier, Isabelle & Quichotte & París & $\begin{array}{l}10 / 2011- \\
1 / 2012\end{array}$ \\
\hline Sterne, Delphyíne & Don Quichotte. Souvenirs d'errance & París & $\begin{array}{l}11- \\
12 / 2003\end{array}$ \\
\hline Strindberg, August & Les clés du ciel & París & $\begin{array}{l}10 / 2009- \\
01 / 2010\end{array}$ \\
\hline Valantin, Émilie & $\begin{array}{l}\text { Vie du grand Dom Quichotte et du } \\
\text { gros Sancho Pança }{ }^{123}\end{array}$ & París & 2009 \\
\hline $\begin{array}{l}\text { Vallot, Juliette (cantos) } \\
\text { Martin, Olivier (puesta en } \\
\text { escena) }\end{array}$ & $\begin{array}{l}\text { L'incomparable aventure aventureu- } \\
\text { se du Chevalier Don Quichotte de } \\
\text { la Mancha }\end{array}$ & La Réunion & $4 / 2010$ \\
\hline Vienne, Anthony & Don Quichotte 124 & Le Quesnoy & 2010 \\
\hline Vintjoux, Philippe & Formidable Don Quichotte & $\begin{array}{l}\text { Villeneuve } \\
\text { de Marsan }\end{array}$ & 2010 \\
\hline
\end{tabular}

122. Obra representada en 2005 en el teatro «Atalante» de París, y, luego, vuelta a interpretar en febrero del 2007 en el «Théâtre des marionnettes» de Estrasburgo; es una adaptación de Peggy Schepens, escenificada por Grégoire Callies, con cuatro actores y 25 marionetas creadas por Yeung Faï; se trata de una succesión de escenas muy visuales, para la defensa del libro y la literatura; domina un tono humorístico y placentero.

123. La obra se estrenó en la «Salle Richelieu» de la Comédie Française; Émilie Valantin, arranca de la obra de José da Silva, de 1733, a la que añade innovaciones escénicas, como la presencia de marionetas-actores sea en tamaño reducido sea de tamaño humano, marionetas que materializan los sueños de Don Quijote; también notamos la presencia de música barroca, cantos y pasajes bailados.

124. La obra se representó en el «Théâtre du Bimberlot». 
Recibido: 20 de enero de 2012

Aceptado: 17 de enero de 2013

\title{
Resumen
}

Este artículo estudia las recreaciones teatrales quijotescas en Francia. Tras una síntesis desde el XVII hasta el 2000, se brinda una serie de datos sobre las principales características estéticas y éticas de estas quijotescas obras contemporáneas.

Palabras clave: Quijote; transculturalidad; reescritura/transescritura; intergenericidad.

Title: "Theatrical recreations of Don Quixote by Miguel de Cervantes Saavedra in France (from the seventeenth to the twenty-first century): review and new data"

\begin{abstract}
This article examines the quixotic dramatic recreations in France. After a synthesis that goes from the seventeenth to 2000 , we provide a set of information about rewrites of the years 2000-2011, in order to reveal the main aesthetic and ethical specificities of contemporary quixotic rewrites.
\end{abstract}

Key words: Quixote; Transculturality; Rewriting/transwriting; Intergenericity. 